\title{
Did Inter-Regional Trade Agreements Bring Mutual Benefits? An Empirical Scheme of Indonesian Commodity Exports in Asean-China Free Trade Area
}

\author{
Andini Nurwulandari ${ }^{1}$, I Made Adnyana $^{1} \&$ Hasanudin $^{1}$ \\ ${ }^{1}$ Faculty of Economics and Business, Universitas Nasional, Jakarta, Indonesia \\ Correspondence: I Made Adnyana, Faculty of Economics and Business, Universitas Nasional, Jakarta 12520, \\ Indonesia.
}

Received: July 29, 2019

Accepted: September 5, 2019

Online Published: September 12, 2019

doi:10.5430/ijfr.v10n6p241

URL: https://doi.org/10.5430/ijfr.v10n6p241

\begin{abstract}
The purpose of the study was to determine the effect of ASEAN-China Free Trade Area (ACFTA) on Indonesia's leading export commodities to China, Hong Kong and ASEAN countries. The methodology used is the model used below is based on New Trade Theory, which involves Comparative Advantage determinants including the total size of the country's economy, similarities in economic size, and differences in relative endowment factors. From the intended purpose, the results of this study are that commodities experiencing the largest growth in exports to all countries in 2010 were commodities with codes: 15, 87, 29 and 40. Meanwhile, commodities with code: 87: Vehicles other than railway or tramway rolling-stock, and parts and accessories thereof, and 27: Mineral fuels, mineral oils and products of their distillation; bituminous substances; mineral waxes, were export commodities whose growth was relatively stable, while commodities with code 26: ores, slag and ash, actually declined, and the potential for Indonesian trade cooperation with ASEAN-4 is still wide open. This was marked by an increase in Indonesia's exports to ASEAN-4 in 2010.
\end{abstract}

Keywords: ACFTA, export-import, trade agreement, ASEAN, Indonesia

\section{Introduction}

Indonesia and other ASEAN members have formed trade cooperation with China ACFTA (ASEAN-China Free Trade Agreement) (Chiang, 2019; Safuan, 2017; Kyophilavong et al., 2017). This is motivated by an increase in the trade of ASEAN countries with China. China is one of ASEAN's main trading partners, while ASEAN is also a supplier of China's needs, especially raw materials (Yang \& Martinez-Zarzoso, 2014). The potential for trade cooperation that is still wide open is realized in the form of the signing of the 2002 cooperation framework. The ACFTA consists of four schemes: Early Harvest Program (EHP), Normal Track (NT) Sensitive Track (ST) and Highly Sensitive Track (HST) (Dordi et al., 2018). The first scheme (EHP) began with eliminating import tariffs starting from 2004 to zero percent in 2006. EHP includes agricultural products HS code 01-08 including live animals, fish, plants, vegetables, etc. The second scheme (NT) began in July 2005 with a target of 0 percent import tariff in 2010 (NT I). NT II is an extension of the NT I retreat option, targeted in 2012. The ST scheme is divided into 3 groups: SensitiveList (SL), Highly SensitiveList (HSL), and general exclusion list (GEL). SL reduced import tariffs to a maximum of 20 percent from 2012 to 2017 and 0-5 percent in 2018. Meanwhile HSL is targeted for 2015 with a maximum tariff of 50 percent. For GEL, it is not liberalized, so the tariff applies to the Most Favored Nation rate (Setiawan, 2012)

Since the beginning of the reduction in import tariffs in the agricultural sector in 2004, the gap between Indonesian exports to China and imports from China has been increasingly gaping. Based on FAO data, Indonesia is starting to enter a trade deficit with China in some commodities such as fruits and vegetables. The invasion of Chinese products has increasingly put pressure on the Indonesian market and Indonesia's exports to China for these commodities have fallen sharply. The volume of fruit imports from China increased almost tenfold from 1999 to 2004 (Tambunan \& Suparyati, 2009; see also, Park et al., 2009; Ishiguro, 2018; Wijaya, 2017). Likewise for vegetable imports which increased 235 times from 1998 to 2004. Contrary to imports, the volume of fruit exports declined 19 times for the same period. The higher Indonesian imports from China due to the implementation of ACFTA could threaten the 
sustainability of the domestic market due to the large scale of the economy and the abundance of cheap labor in China. Local labor-based commodities must compete hard with Chinese products. In addition to the negative impact of ACFTA on Indonesian exports, especially in the agricultural sector there are some parties who state that in general, the ACFTA has a positive impact on Indonesian trade. Marks (2012) analyzes the trade in ACFTA from 2010 using a comprehensive partial-equilibrium model. The result of the study is that overall Indonesia experienced a positive trade balance from the ACFTA, even though it experienced a trade deficit with China. Ibrahim et al. (2010) in the analysis with CGE model concluded that net trade creation from Indonesia's international trade was 2 percent and export growth increased 1.8 percent. Besides Indonesia, the increase in exports of ASEAN countries to China is also experienced by Malaysia, Singapore and Thailand.

Using the ARIMA econometric model, Setiawan (2012) analyzes the influence of ACFTA on Indonesian and Chinese exports. The forecasting result with ARIMA is used as a simulation export value if there is no application of ACFTA. From the model output, Indonesia's export growth has increased by an average of 5.8 percent per year since the reduction in the import tariff for the ACFTA scheme came into effect. This value is equal to the increase in export growth of 1.36 times compared to the absence of the ACFTA scheme. Meanwhile for China, the ACFTA scheme increases the average export growth far more than Indonesia, which is 18.6 percent per year or an increase of 7.7 times. Most of the commodities traded in the ASEAN market and China are natural resource-based commodities, such as CPO and rubber. The biggest benefit of ACFTA in Indonesia is seen in textiles and products from textiles, machinery and electrical equipment, and other industries (see also, Fakhrudin, 2011). According to Yue (2004) there was a significant increase in intra-industrial trade. There are still opportunities for export diversification to increase Indonesia's exports, especially industry-based commodities. The increasing number of frameworks for international trade cooperation between Indonesia and other countries has aroused interest in seeing more detail in the leading commodities and ASEAN markets. Accordingly, based on the initial research by Adnyana (2018) this paper aims to empirically investigate the effect of ACFTA on Indonesia's leading export commodities to foreign market, with taking examples of China, Hong Kong and ASEAN.

\section{Methodology}

The export destination countries analyzed in this study are the main trading partner countries in China, Hong Kong, and ASEAN-4 (Malaysia, Philippines, Singapore, Thailand). The data used in this study are quarterly export value data from 1996 to 2013. The selection of the main commodities of Indonesian exports is based on the total value of Indonesia's export transactions according to the HS chapter of the six selected countries as follows:

27: Mineral fuels, mineral oils and products of their distillation; bituminous substances; mineral waxes

85. Electrical machinery and equipment and parts thereof; sound recorders and reproducers, television image and sound recorders and reproducers, and parts and accessories of such article

15: animal or vegetable fats and oils and their cleavage products; prepared edible fats; animal or vegetable waxes

84: Nuclear reactors, boilers, machinery and mechanical appliances; parts thereof

26: Ores, slag and ash

40: Rubber and articles thereof

74: Copper and articles thereof

29: Organic Chemicals

87: Vehicles other than railway or tramway rolling-stock, and parts and accessories thereof

48: Paper and paperboard; articles of paper pulp, of paper or of paperboard

On average, the total exports of Indonesia's ten main commodities to destination countries in this study contributed 69.41 percent. The highest share was in chapter 27, which was 27.86 percent and followed by chapter 85 by 9.75 percent. The commodity is included in the NT (Normal Track) scheme, so that the determination of the entry into force of the ACFTA scheme for the variable dummy is to see the import tariff become 0 percent, namely January 2010. In the NT scheme, starting January 2010, the import tariff is targeted to be 0 percent with an extension up to 2012.

To see the effect of ACFTA on Indonesian exports in each of the leading commodities in this study, the OLS regression model was used. As the dependent variable is Indonesia's exports to the destination country at time-t. Meanwhile the independent variables that will be used: the value of the export of the previous period, the total GDP 
of the country of origin and destination, the Similarity Index, Relative Factor Endowment (RFE), the exchange rate, the last is ACFTA as a dummy variable).

The model used below is based on New Trade Theory, which involves Comparative Advantage determinants including total economic size of the country, similarities in economic size, and differences in relative endowment factors (Baltagi et al., 2017; Balazsi et al., 2018; Gil-Pareja et al., 2018; Baltagi et al., 2003).

$\mathrm{TGDP}_{\mathrm{Ijt}}=\ln \left(\mathrm{GDP}_{\mathrm{It}}+\mathrm{GDP}_{\mathrm{jt}}\right)$

Relative Factor Endowment $\left(\mathrm{RFE}_{\mathrm{Ijt}}\right)=\left|\ln \left(\frac{G D P_{I t}}{P O P_{I t}}\right)-\ln \left(\frac{G D P_{j t}}{P O P_{j t}}\right)\right|$

Similarity index $\left(\mathrm{SI}_{\mathrm{Ijt}}\right)=\ln \left[1-\left(\frac{G D P_{I t}}{G D P_{I t}+G D P_{I t}}\right)^{2}-\left(\frac{G D P_{j t}}{G D P_{I t}+G D P_{j t}}\right)^{2}\right]$

TGDP $=$ total GDP of Indonesia and destination country at time-t

$\mathrm{RFE}=$ measures the difference in endowment capital at t-time, which is illustrated by the difference in GDP per capita in Indonesia and the destination country. Per capita GDP here is an approach to the capital-labor ratio. The greater the difference in capital endowment, the less the volume of intra-industry trade.

According to the Heckscher-Ohlin theorem (see in Coşar \& Fajgelbaum, 2016; Burstein \& Vogel, 2017), endowment factors that are increasingly different between countries will further trigger international trade. Meanwhile, according to the Linder hypothesis (see for instance in Kabir et al., 2017; Viciu et al., 2016), trade will actually occur in two countries that have the same economic needs, reflected by differences in endowment factors that tend to be small. Similar economic size (SI) and similar endowment (RFE) factors allow more trade transactions. This is what underlies the intra-industry trade theorem.

$\mathrm{SI}=$ reflects the similarity between Indonesia and the destination country.

RER $=$ a decline in a country's domestic currency will cause a decline in the relative price of exports, thereby increasing the value of its exports. Conversely, the relative price of imports will decrease, causing the import value to decline. The real exchange rate is the nominal exchange rate between countries divided by the ratio of each price index.

$$
\operatorname{RER}_{\mathrm{Ijt}}=\mathrm{e}_{\mathrm{Ijt}} \frac{\mathrm{CPI}_{\mathrm{jt}}}{\mathrm{CPI}_{\mathrm{It}}}
$$

Where:

$\mathrm{e}_{\mathrm{Ijt}}=$ the nominal exchange rate of Indonesia and the destination country at time-tXXX

$\mathrm{CPI}_{\mathrm{jt}}=$ Destination country CPI at $\mathrm{t}$-time

$\mathrm{CPI}_{\mathrm{It}}=$ Country of origin CPI at t-time

The OLS regression model used in this study is:

$$
\ln X_{\mathrm{Ijt}}=\beta_{0}+\beta_{1} \mathrm{X}_{\mathrm{Ij}(\mathrm{t}-1)}+\beta_{2} \mathrm{TGDP}_{\mathrm{Ijt}}+\beta_{3} \mathrm{SI}_{\mathrm{Ijt}}+\beta_{4} \mathrm{RFE}_{\mathrm{Ijt}}+\beta_{5} \operatorname{lnRER}_{\mathrm{Ijt}}+\beta_{5} \mathrm{ACFTA}_{\mathrm{Ijt}}+\varepsilon_{\mathrm{Ijt}}
$$

Where:

$\mathrm{X}_{\mathrm{Ijt}}=$ Indonesian exports to $\mathrm{j}$-country at $\mathrm{t}$-time

$\mathrm{X}_{\mathrm{Ij}(\mathrm{t}-1)}=$ Indonesian exports to Country-j at time-t-1

$\mathrm{TGDP}_{\mathrm{Ijt}}=$ total GDP of Indonesia and country-j in time-t

$\mathrm{SI}_{\mathrm{Ijt}}=$ Similarity Index, as explained earlier

$\mathrm{RFE}_{\mathrm{Ijt}}=$ Relative Factor Endowment, as explained earlier

$\mathrm{RER}_{\mathrm{Ijt}}=$ The exchange rate of Rupiah and State-j in time-t

ACFTA $_{\mathrm{Ijt}}=$ The dummy variable, is worth 1 if Indonesia-j in time-t is in the ACFTA scheme, namely quarter I / 2010 as the 0 percent import tariff benchmark for NT 


\section{Indonesia-China Trade Relations}

Imports dominated the trade of Chinese-Indonesia since 1996. From 1996-2007, Indonesia experienced a trade surplus with China, but there were changes from 2008 to 2013. Imported commodities from China which experienced an increase were $74,85,84,15$. In the year 2008 there was a surge in imports caused by additional coverage of bonded zones. In 2009, Indonesia's export and import to China decreased by minus 1 and minus 8 percent. On the other hand, exports and imports to and from China in 2010 returned to positive growth. This can be caused by the economy is recovering from the shock of the global economic crisis in 2009. In addition, the growth of trade between Indonesia and China can occur due to the reduction of import tariffs on the ACFTA scheme.

The reduction in import tariffs on ACFTA is considered beneficial for several companies, because imported industrial raw materials will be more easily obtained, with very cheap prices. Exports to China in 2010 decreased for commodities with code: 84 . Selected commodities contributed around 72 percent of total exports to China . From 1996-2013, the highest share of 10 commodities selected for total was in 2011, which was 85 percent. Commodity with code: 27 is the main export commodity, followed by commodities with code: 15 .

Table 1. OLS Indonesia-China regression output

\begin{tabular}{|c|c|c|c|c|c|c|c|c|c|c|c|}
\hline \multirow{2}{*}{ Variable } & \multicolumn{11}{|c|}{ Commodities } \\
\hline & 15 & 27 & 84 & 85 & 26 & 29 & 40 & 48 & 74 & 87 & TOTAL \\
\hline $\mathrm{C}$ & $-32.41 * *$ & $-28.41 * * *$ & -17.04 & $-17.44 * *$ & $-245.42 * * *$ & $13.07 * *$ & $-24.03 *$ & $18.38 * * *$ & -1.62 & -70.61 & $-14.15^{* * *}$ \\
\hline PREV_X & $0.29 * * *$ & $0.35^{* * *}$ & $0.63 * * *$ & $0.69 * * *$ & 0.15 & $0.78 * * *$ & $0.76^{* * *}$ & $0.42 * * *$ & $0.82 * * *$ & 0.07 & $0.46^{* * *}$ \\
\hline TGDP & $3.53 * * *$ & $2.98^{* * *}$ & $1.73^{* *}$ & $1.35^{* * *}$ & $17.83^{* * *}$ & -0.41 & $1.90^{*}$ & -0.52 & 0.73 & $8.11 * *$ & $1.80^{* * *}$ \\
\hline SI & $5.55^{* *}$ & 2.29 & $4.56^{*}$ & 0.94 & 20.14 & 2.04 & 3.79 & 0.46 & $6.78 * * *$ & $37.26 * * *$ & 1.42 \\
\hline RFE & 0.64 & $1.02 *$ & 0.80 & $1.06^{* *}$ & $10.17 *$ & $-0.81 *$ & $1.51 * *$ & -0.36 & -0.05 & 2.64 & $0.56^{*}$ \\
\hline RER & 0.21 & 0.16 & -0.08 & $-0.33 * * *$ & -0.38 & 0.04 & -0.16 & -0.01 & 0.12 & $1.23^{*}$ & 0.01 \\
\hline ACFTA & $-0.54 * *$ & -0.26 & $-0.51^{*}$ & -0.13 & -2.17 & 0.09 & 0.02 & 0.00 & -0.13 & -0.62 & -0.09 \\
\hline R-square & 0.906 & 0.905 & 0.883 & 0.954 & 0.540 & 0.948 & 0.930 & 0.409 & 0.956 & 0.492 & 0.971 \\
\hline
\end{tabular}

$*, * *, * * *$ respectively are significant at the real level $10 \%, 5 \%$ and $1 \%$

In Indonesia's exports to China in 1996-2013, the OLS regression model on average was able to explain export variations well, which was above 88 percent. However, for commodities with codes: 48 and 87 , the OLS model only explains the variation of the model below 50 percent. Exports as a sustainable process can be seen in the export variable in the previous quarter, where all coefficients are significant at 1 percent and are positive, except for commodities with codes: 26 and 87. Among all major commodities, total GDP plays the biggest role in 15 export commodities.

Indonesia's exports to China for commodities with codes of 27, 85, 26, 40, and total are more based on differences in endowment factors, so they are not in accordance with the intra-industry trade. However, only 29 commodity exports to China are based on the similarity of endowment factors and are in line with the intra-industry trade. RER is significant and negative only for commodities with code: 85 . Unlike economic theory, the regression output states that every percent depreciation of the Rupiah actually decreases the export value by 0.33 percent. Meanwhile, for commodity with code: 87 , RER is actually a positive value, which means that every time the depreciation of the Rupiah will encourage the value of commodity exports 87 by 1.24 percent. In other commodities, depreciation does not affect the value of exports to China.

The implementation of the ACFTA trade cooperation scheme was not in line with expectations, that it turned out that the ACFTA had a negative impact on Indonesian exports to China, especially in commodities with codes: 15 and 84 . The ACFTA was unable to increase Indonesia's exports to major commodities, but instead weakened the export value of these commodities. Exports to other commodities are not affected by ACFTA.

\section{Indonesian-HK Trade Relations}

Indonesian-HK trade cooperation from 1996-2013 was dominated by exports. The main export commodity is commodity with code: 27 . In 2008, imports from Hong Kong jumped 435 percent from the previous year, which was 
driven by 6 selected commodities whose growth was more than 230 percent. This is due to the additional coverage of bonded areas. Although Indonesia is still experiencing a trade surplus with HK, its value is shrinking.

Table 2. OLS Indonesia - Hong Kong regression output

\begin{tabular}{|c|c|c|c|c|c|c|c|c|c|c|c|}
\hline \multirow{2}{*}{ Variable } & \multicolumn{11}{|c|}{ Commodities } \\
\hline & 15 & 27 & 84 & 85 & 26 & 29 & 40 & 48 & 74 & 87 & Total \\
\hline $\mathrm{C}$ & $42.35^{*}$ & $-43.98 * * *$ & -2.69 & $-18.82 * *$ & -118.98 & $99.52 * * *$ & $-36.81 * * *$ & $24.15^{* *}$ & $-42.53 * * *$ & 6.38 & 3.20 \\
\hline PREV_X & $0.48^{* * * *}$ & $0.39 * * *$ & $0.75^{* * *}$ & $0.41 * * *$ & 0.16 & -0.07 & $0.34 * *$ & $0.40 * * *$ & $0.69 * * *$ & $0.44 * * *$ & $0.63 * * *$ \\
\hline TGDP & 1.26 & 0.18 & -1.16 & 0.21 & $37.86 * * *$ & 2.54 & $-1.99 *$ & -0.55 & -1.58 & 1.88 & 0.63 \\
\hline SI & 19.02 & $-19.08 * * *$ & -7.69 & -9.06 & 142.05 & $43.32 * * *$ & $-27.19 * * *$ & 2.28 & $-24.97 * * *$ & 7.25 & 1.53 \\
\hline RFE & -13.03 & $15.47 * *$ & 7.13 & 9.50 & -126.28 & $-34.56 * * *$ & $23.79 * * *$ & -1.74 & $22.79 * * *$ & -6.97 & -1.42 \\
\hline RER & 0.06 & 0.10 & -0.05 & 0.02 & -2.09 & $-0.47 * *$ & $0.43 * *$ & 0.01 & $0.35^{* * *}$ & $0.55 * *$ & 0.02 \\
\hline ACFTA & -0.19 & $-0.23 *$ & 0.01 & 0.08 & $-4.09 *$ & -0.13 & -0.26 & 0.01 & -0.11 & -0.18 & 0.04 \\
\hline R-square & 0.732 & 0.928 & 0.728 & 0.886 & 0.640 & 0.627 & 0.508 & 0.792 & 0.889 & 0.652 & 0.846 \\
\hline
\end{tabular}

$*, * *, * * *$ respectively are significant at the real level $10 \%, 5 \%$ and $1 \%$

Exports in the previous period have an important role in current period exports, reflected in almost all major commodities that are significant and positive, except commodities 26 and 29.

SI and RFE variables in the significant model of commodity exports with codes: 27, 29, 40, and 74. Indonesian exports to Hong Kong for these commodities (except code: 29) are not in accordance with the intra-industry trade. As with Indonesian exports to China, export commodities with code: 29 are based more on classical international trade theory, namely comparative advantage.

The ACFTA trade scheme has a negative impact on Indonesia's exports to Hong Kong commodities with codes of 27 and 26, in contrast to Indonesia's export commodities to China which were negatively affected. However, the ACFTA does not have any influence on other commodities.

\section{Indonesia-ASEAN-4 Trade Relations}

\subsection{Malaysia}

Indonesian trade with Malaysia has always been dominated by exports. Although in 2008, Indonesia experienced a trade deficit with Malaysia. The main export commodity is commodity with code 27 . This commodity began to rank first in 2000. This commodity also became the main import commodity from Malaysia. Indonesian exports to Malaysia are based more on comparative advantages based on differences in endowment factors in commodities with codes of $84,85,29,48$ and 87.

Table 3. OLS Indonesia-Malaysia regression output

\begin{tabular}{|c|c|c|c|c|c|c|c|c|c|c|c|}
\hline \multirow{2}{*}{ Variable } & \multicolumn{11}{|c|}{ Commodities } \\
\hline & 15 & 27 & 84 & 85 & 26 & 29 & 40 & 48 & 74 & 87 & Total \\
\hline $\mathrm{C}$ & -4.90 & -2.67 & 27.02 & $87.97 * * *$ & 289.42 & $50.47 *$ & $44.09 *$ & $78.29 * * *$ & $127.62 *$ & $144.20 * * *$ & 9.95 \\
\hline PREV_X & $0.75 * * *$ & $0.32^{* *}$ & $0.71 * * *$ & $0.41 * * *$ & $0.28 * *$ & $0.33^{* *} *$ & $0.41 * * *$ & 0.03 & $0.26^{*}$ & 0.16 & $0.52 * * *$ \\
\hline TGDP & 0.96 & $2.10 * * *$ & -0.28 & -0.62 & -7.62 & -0.68 & -0.26 & $-1.30 * * *$ & -2.95 & -1.02 & $0.71 * *$ \\
\hline SI & 2.11 & 8.71 & 10.23 & $38.53 * * *$ & 111.84 & $19.11^{* *}$ & $19.68 *$ & $25.94 * * *$ & $48.95 *$ & $65.09 * * *$ & $6.04 *$ \\
\hline RFE & 1.46 & 6.11 & $9.60 *$ & $36.73 * * *$ & 86.85 & $16.60^{*}$ & 14.54 & $20.84 * * *$ & 36.27 & $53.55^{* * *}$ & 4.85 \\
\hline RER & -0.03 & -0.31 & 0.19 & $0.89 * * *$ & -1.87 & -0.31 & $-0.48 * *$ & -0.17 & $-1.56 * *$ & 0.57 & -0.09 \\
\hline ACFTA & -0.19 & 0.14 & 0.06 & 0.19 & -1.38 & -0.26 & -0.13 & -0.01 & $-0.70 *$ & $-0.41^{*}$ & -0.00 \\
\hline $\mathrm{R}$-square & 0.858 & 0.954 & 0.739 & 0.761 & 0.337 & 0.868 & 0.945 & 0.884 & 0.880 & 0.897 & 0.978 \\
\hline
\end{tabular}

$*, * *, * * *$ respectively are significant at the real level $10 \%, 5 \%$ and $1 \%$ 


\subsection{Philippines}

Indonesia-Philippines trade is dominated by exports from year to year. Until 2013, commodity with code of 27 was Indonesia's mainstay export commodity to the Philippines, which contributed more than 20 percent. Exports to the Philippines are based on differences in endowment factors, namely commodities with codes of 15,74 and 87.

Table 4. OLS regression output Indonesia - Philippines

\begin{tabular}{|c|c|c|c|c|c|c|c|c|c|c|c|}
\hline \multirow{2}{*}{ Variable } & \multicolumn{11}{|c|}{ Commodities } \\
\hline & 15 & 27 & 84 & 85 & 26 & 29 & 40 & 48 & 74 & 87 & Total \\
\hline $\mathrm{C}$ & 31.02 & $-47.43 * *$ & 11.22 & 0.21 & -86.81 & 10.31 & 8.91 & 10.88 & $120.37 * * *$ & 22.26 & -0.47 \\
\hline PREV_X & $0.36^{* * *}$ & $0.34 * * *$ & $0.38 * * *$ & $0.84 * * *$ & 0.00 & $0.36^{* * *}$ & $0.26 * *$ & $0.50 * * *$ & $0.22 *$ & $0.66^{* * *}$ & $0.23^{*}$ \\
\hline TGDP & 0.04 & $3.34 * * *$ & 0.39 & 0.26 & 6.03 & 0.15 & 1.05 & 0.16 & $-3.52 *$ & -0.19 & $1.38 * * *$ \\
\hline SI & $36.68^{*}$ & -19.82 & 15.00 & 1.68 & -36.76 & 7.21 & 16.29 & 9.21 & $95.15 * * *$ & $21.29 *$ & 5.50 \\
\hline RFE & $32.07 *$ & -17.69 & 13.62 & 1.40 & -32.16 & 6.52 & 14.24 & 8.28 & $84.69 * * *$ & $18.57 *$ & 4.84 \\
\hline RER & -0.26 & -0.39 & $-0.38 * *$ & -0.00 & 0.17 & -0.28 & 0.27 & -0.06 & 0.59 & 0.05 & -0.04 \\
\hline ACFTA & -0.31 & 0.10 & -0.09 & -0.03 & $-4.73 *$ & 0.24 & 0.11 & 0.06 & -0.26 & 0.02 & 0.07 \\
\hline $\mathrm{R}$-square & 0.872 & 0.851 & 0.917 & 0.922 & 0.095 & 0.831 & 0.845 & 0.872 & 0.759 & 0.942 & 0.958 \\
\hline
\end{tabular}

\subsection{Singapore}

From 1996-2004, the main commodities of exports to Singapore were commodities with codes: 85,84 and 27. The share of commodities with code of 27 from year to year was increasing, reaching 38 percent in 2013, while from 2005-2013, Indonesia experienced a trade deficit with Singapore. Even, imports of commodities with code 27 reached 60 percent.

Table 5. OLS regression output Indonesia - Singapore

\begin{tabular}{|c|c|c|c|c|c|c|c|c|c|c|c|}
\hline \multirow{2}{*}{ Variable } & \multicolumn{11}{|c|}{ Commodities } \\
\hline & 15 & 27 & 84 & 85 & 26 & 29 & 40 & 48 & 74 & 87 & Total \\
\hline $\mathrm{C}$ & $-40.20 * *$ & $22.37 * *$ & 0.18 & -5.39 & $-480.51 * * *$ & 5.81 & -7.82 & $52.77 * * *$ & $-36.92 *$ & 4.85 & $10.26^{* *}$ \\
\hline PREV_X & 0.14 & $0.33^{* * * *}$ & $0.70 * * *$ & $0.56^{* * *}$ & $-0.21 *$ & $0.58 * * *$ & $0.74 * * *$ & -0.08 & $0.57 * * *$ & $0.32 * * *$ & $0.41 * * *$ \\
\hline TGDP & $2.83 * * *$ & 0.62 & 0.05 & 0.14 & $20.45 * * *$ & -0.26 & 0.27 & $-1.78 * * *$ & $1.47 *$ & $0.66^{*}$ & $0.40 * *$ \\
\hline SI & -3.44 & $5.84^{* * * *}$ & -1.10 & $-3.19 * *$ & $-66.17 * *$ & -0.53 & -2.18 & $4.51 * *$ & $-6.26^{*}$ & 0.75 & 1.35 \\
\hline RFE & 3.98 & -3.03 & 1.33 & $3.58 * * *$ & 27.32 & 2.22 & $3.71 * * *$ & -1.84 & $6.83 * *$ & 0.38 & -0.18 \\
\hline RER & $-0.60 * * *$ & 0.08 & $-0.11^{*}$ & $-0.13 * * *$ & $-3.61 * * *$ & -0.16 & -0.01 & $-0.30 * * *$ & $-0.30 * *$ & $0.09^{*}$ & -0.02 \\
\hline ACFTA & -0.25 & 0.11 & -0.08 & 0.11 & $-6.27 * * *$ & 0.00 & -0.15 & -0.10 & -0.46 & 0.13 & -0.02 \\
\hline R-square & 0.908 & 0.913 & 0.857 & 0.833 & 0.451 & 0.662 & 0.912 & 0.583 & 0.810 & 0.817 & 0.941 \\
\hline
\end{tabular}

$*, * *, * * *$ respectively are significant at the real level $10 \%, 5 \%$ and $1 \%$

\subsection{Thailand}

In general, Indonesia has a trade deficit with Thailand. There has been a trade surplus with Thailand, namely in 1998, 2001 and 2002. However, the trade surplus in that period was a maximum of 11 percent. The main commodity of Indonesian exports to Thailand is commodity with code 27 . The export of this commodity to Thailand is based more on comparative advantage. Likewise, exports of commodities were in classification codes of $84,74,87$ and total. 
Table 6. OLS regression output Indonesia - Thailand

\begin{tabular}{|c|c|c|c|c|c|c|c|c|c|c|c|}
\hline \multirow{2}{*}{ Variable } & \multicolumn{11}{|c|}{ Commodities } \\
\hline & 15 & 27 & 84 & 85 & 26 & 29 & 40 & 48 & 74 & 87 & Total \\
\hline $\mathrm{C}$ & 45.02 & $-36.97 * * *$ & $-25.71 * * *$ & 3.13 & -160.1 & 2.9147 & 26.979 & 3.0344 & -31.96 & $-43.66^{* *}$ & $-12.32 * * *$ \\
\hline PREV_X & 0.09 & 0.19 & $0.47 * * *$ & $0.56^{* * *}$ & 0.14 & $0.62 * * *$ & $0.42 * * *$ & $0.50 * * *$ & $0.43 * * *$ & $0.40^{* * *}$ & $0.21 *$ \\
\hline TGDP & -6.68 & $5.27 * * *$ & $4.10 * * *$ & 0.663 & 23.5 & 0.67 & 2.07 & 0.98 & $7.12 * *$ & $7.45^{* * *}$ & $2.88 * * *$ \\
\hline SI & -64.86 & $23.45^{* *}$ & $26.64 * * *$ & 6.644 & 206. & 7.68 & 60.2 & 11.3 & $75.0 * *$ & $62.4 * * *$ & $14.3 * * *$ \\
\hline RFE & -64.47 & $19.94 * *$ & $22.91 * * *$ & 5.454 & 191. & 6.39 & 46.1 & 8.74 & $64.5^{* *}$ & $53.4 * * *$ & $12.0 * * *$ \\
\hline RER & $-2.30 * *$ & $-0.28 * *$ & $-0.51 * * *$ & $-0.31 * * *$ & -1.49 & $-0.26^{*}$ & $-2.76 * * *$ & $-0.60 * * *$ & $-2.05 * * *$ & $-1.53 * * *$ & $-0.37 * * *$ \\
\hline ACFTA & -0.30 & 0.01 & 0.211 & 0.235 & $6.278^{*}$ & 0.167 & 0.513 & 0.078 & 0.654 & 0.584 & $0.232 * *$ \\
\hline $\mathrm{R}$-square & 0.567 & 0.895 & 0.939 & 0.900 & 0.218 & 0.769 & 0.710 & 0.921 & 0.851 & 0.943 & 0.962 \\
\hline
\end{tabular}

$*, * *, * * *$ respectively are significant at the real level $10 \%, 5 \%$ and $1 \%$

In total, Indonesia's exports to Malaysia, the Philippines, Singapore and Thailand are dynamic, and have a close relationship with the previous period's exports. The total GDP of Indonesia and all ASEAN-4 countries is very influential on Indonesia's exports when viewed in total commodities. Commodity exports to Thailand for commodity with code of 26 are not affected by depreciation. Meanwhile, depreciation actually weakens the value of exports of other major commodities. Economic theory which states that depreciation will increase the value of exports is not proven in exports to Thailand. Likewise Indonesian exports to Singapore, for exports of commodities with codes of $15,84,85,26,48,74$, and 87 actually weakened with the depreciation of the Rupiah.

The ACFTA scheme has a positive impact on Indonesian exports to Thailand for commodities with code of 26 and in total. However, the contribution of commodities with code of 26 to Indonesian exports to Thailand is very small, as well as the variation of exports in the OLS model of commodities in classification code of 26 is very small. With the enactment of the ACFTA, exports to the Philippines and Singapore for commodities with code 26 were negatively affected. Meanwhile, commodities that are negatively affected by the presence of ACFTA on exports to Malaysia are commodities with code 74. The rest, the ACFTA does not have any influence on Indonesia's exports to ASEAN-4 countries. In general, the ACFTA has a negative impact on Indonesia's exports of certain commodities in the sample destination countries, except Thailand.

\section{Conclusion}

The results show that commodities experiencing the largest growth in exports to all countries in 2010 were commodities with codes of 15, 87, 29 and 40, while commodities in the codes of 87 and 27 were export commodities whose growth was relatively stable. However, commodities with code 26 actually declined. The potential for Indonesian trade cooperation with ASEAN-4 is still wide open. This was marked by an increase in Indonesia's exports to ASEAN-4 in 2010. Like exports, in 2010 imports also experienced a recovery. Although Indonesia's exports to ASEAN-4 had experienced a decline in 2009 due to the global economic crisis, but after the ACFTA framework with 0 percent import tariffs came into effect, exports returned to improving. Weakening of trade due to the global economic crisis did not only occur in exports, but imports also contracted by minus 30 percent. Among other ASEAN countries, Indonesia, together with India and China, is a country that is able to survive during the global economic crisis and still experience positive economic growth. However, because other ASEAN countries experienced severe shocks, the flow of Indonesia's international trade to ASEAN countries was also affected. Although the global economic crisis was not as severe as the Asian economic crisis in 1998, the global economic crisis was more in need of a long recovery time.

In order to welcome the AEC1515 (ASEAN Economic Community) as a more comprehensive step than the AFTA (Asean Free Trade Area), one of which is to make ASEAN a single market and production base. It is hoped that Indonesia will not only be a lucrative target market for importing countries, but also able to compete with other ASEAN countries. This is because the population of Indonesia is 40 percent of the total population of ASEAN. Indonesia still has the opportunity to increase export value added. The ability to use technology, networking, market penetration, trade negotiation capabilities, and infrastructure improvements is absolutely enhanced by business people and policy makers. 
In terms of limitation, this study only discusses exports, only the positive effects that arise from the scheme of ACFTA cooperation in Indonesia. Additionally, the negative impact of imports was traced from 2008 due to the addition of coverage of bonded zones. The next study is expected to broaden the scope of reciprocal export-import schemes between China and ASEAN as a whole, so that the effect of imports from China on the ASEAN countries as a whole or partially can be seen. Future studies are also expected to develop a focus in examining efforts to enlarge, and the mutual effects of, trade in these two regions. In addition, the effect of the trade war between China and the US can also be studied more deeply on the quantity of trade in the ACFTA scheme.

\section{References}

Adnyana, M. (2018). Riview skema ACFTA terhadap ekspor INDONESIA ke Tiongkok, Hongkong dan Asean. Jurnal Sosial dan Humaniora, 1(1). https://doi.org/10.14710/jdep.1.2.1-9

Balazsi, L., Matyas, L., \& Wansbeek, T. (2018). The estimation of multidimensional fixed effects panel data models. Econometric Reviews, 37(3), 212-227. https://doi.org/10.1080/07474938.2015.1032164

Baltagi, B. H., Egger, P. H., \& Erhardt, K. (2017). The estimation of gravity models in international trade. In The Econometrics of Multi-dimensional Panels (pp. 323-348). Springer, Cham. https://doi.org/10.1007/978-3-319-60783-2_11

Baltagi, B. H., Egger, P., \& Pfaffermayr, M. (2003). A generalized design for bilateral trade flow models. Economics Letters, 80(3), 391-397. https://doi.org/10.1016/S0165-1765(03)00115-0

Burstein, A., \& Vogel, J. (2017). International trade, technology, and the skill premium. Journal of Political Economy, 125(5), 1356-1412. https://doi.org/10.1086/693373

Coşar, A. K., \& Fajgelbaum, P. D. (2016). Internal geography, international trade, and regional specialization. American Economic Journal: Microeconomics, 8(1), 24-56. https://doi.org/10.1257/mic.20140145

Dordi, C., Nguyen, D. A., Vanzetti, D., Trewin, R., Dinh, H. T., Vu, H. T., \& Le, S. X. (2018). Assessing the Impacts of the Regional Comprehensive Economic Partnership on Vietnam's Economy. EU-MUTRAP Project.

Fakhrudin, U. (2011). The competitiveness of Indonesian product in trade relationship with China. Buletin Ilmiah Litbang Perdagangan, 5(2), 164-176.

Gil-Pareja, S., Llorca-Vivero, R., \& Martínez-Serrano, J. A. (2017). The effect of nonreciprocal preferential trade agreements on benefactors' exports. Empirical Economics, 52(1), 143-154. https://doi.org/10.1007/s00181-016-1071-y

Chiang, M. H. (2019). China-ASEAN economic relations after establishment of free trade area. The Pacific Review, 32(3), 267-290. https://doi.org/10.1080/09512748.2018.1470555

Ibrahim, I., Permata, M. I., \& Wibowo, W. A. (2010). Dampak pelaksanaan ACFTA terhadap perdagangan internasional Indonesia. Buletin Ekonomi Moneter dan Perbankan, 13(1), 23-74.

Ishiguro, K. (2018). Preferential trade agreements under declining American Hegemony. International Journal of Financial Research, 9(1), 163-170. https://doi.org/10.5430/ijfr.v9n1p163

Kabir, M., Salim, R., \& Al-Mawali, N. (2017). The gravity model and trade flows: Recent developments in econometric modeling and empirical evidence. Economic Analysis and Policy, 56, 60-71.

Kyophilavong, P., Wong, M. C., Souksavath, S., \& Xiong, B. (2017). Impacts of trade liberalization with China and Chinese FDI on Laos: evidence from the CGE model. Journal of Chinese Economic and Business Studies, 15(3), 215-228. https://doi.org/10.1080/14765284.2017.1346923

Marks, S. V. (2012). Impact on Indonesia of the ASEAN-China Free Trade Agreement. United States Agency for International Development.

Park, D., Park, I., \& Estrada, G. E. B. (2009). Prospects for ASEAN-China free trade area: A qualitative and quantitative analysis. China \& World Economy, 17(4), 104-120.

Safuan, S. (2017). ASEAN-China Free Trade Area: An Assessment of Tariff Elimination Effect on Welfare. European Research Studies, 20(4B), 27-37.

Setiawan, S. (2012). Asean-China FTA: Dampaknya Terhadap Ekspor Indonesia dan Cina. Buletin Ilmiah Litbang Perdagangan, 6(2), 129-150. 
Tambunan, T., \& Suparyati, A. (2009). ASEAN-China Trade Liberalisation Effect on Indonesian Agricultural Production and Trade. Policy discussion paper series. Center For Industry, SME \& Business Competition Studies, Trisakti University.

Viciu, T. G., Mihoreanu, L., \& Costea, C. (2016). An essay on the applicability of the Linder hypothesis in determining the patterns of the Romanian international trade. Journal of Economic Development, Environment and People, 5(1), 52-62. https://doi.org/10.26458/jedep.v5i1.130

Wijaya, E., Nopiandri, K., \& Habiburrokhman, H. (2017). Dinamika Upaya Melakukan Sinergi Antara Hukum Perdagangan Internasional Dan Hukum Lingkungan. Jurnal Hukum dan Peradilan, 6(3), 487-508.

Yang, S., \& Martinez-Zarzoso, I. (2014). A panel data analysis of trade creation and trade diversion effects: The case of ASEAN-China Free Trade Area. China Economic Review, 29, 138-151.

Yue, C. S. (2004, April). ASEAN-China free trade area. In AEP Conference (pp. 12-13). 